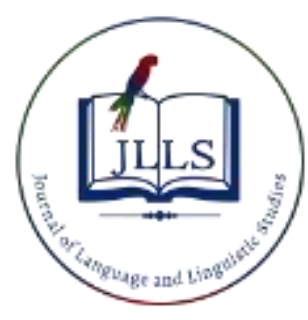

Available online at www.jlls.org

JOURNAL OF LANGUAGE AND LINGUISTIC STUDIES

ISSN: $1305-578 \mathrm{X}$

Journal of Language and Linguistic Studies, 16(2), 809-821; 2020

\title{
The relationship among academic success scores of graded foreign language
} courses

\author{
Recep Gür a (iD), Barış Eriçok ${ }^{\text {b }}$ (D) \\ ${ }^{a}$ Anadolu University, Eskişehir, Turkey \\ APA Citation: \\ ${ }^{b}$ Nevșehir Hacı Bektaș Veli University, Nevșehir, Turkey
}

Gür, R., \& Eriçok, B. (2020). The relationship among academic success scores of graded foreign language courses. Journal of Language and Linguistic Studies, 16(2), 809-821.

Submission Date:10/09/2019

Acceptance Date:25/01/2020

\begin{abstract}
The problem of this study is to find out how the academic success scores of the graded foreign language courses such as Foreign Language I, II, III, IV, V and VI have a relationship among them and to what extent these courses are actually prerequisite to each other. The model of the study is correlational survey model. The research group consists of 194 students that took the graded Foreign Language courses at the faculty of tourism in a public university in Turkey. As a result of the research, it is found out that Foreign Language I and II courses and Foreign Language III, IV, V, VI courses are graded among themselves. Moreover, students' academic success scores of Foreign Language I and II courses are found to be significantly higher than those of other courses. Therefore, when a holistic evaluation is made in line with the limitations of the research, it can be said that Foreign Language I, II, III, IV, V, VI courses are not graded among themselves. It is recommended that these courses, which are graded in terms of names, subjects and books used, can be arranged to be graded in real terms in accordance with Bloom's Mastery Learning Model. In this context, it should be ensured that this graduality is taken into consideration during the selection of graded foreign language courses by students. It is recommended to make necessary regulations that prevent students who fail any level of graded foreign language courses from taking the upper level course(s).
\end{abstract}

C 2020 JLLS and the Authors - Published by JLLS.

Keywords: graded English courses; academic success scores; prerequisite courses; mastery learning; English as a foreign language

\section{Introduction}

According to a common sense in Africa, a new-born baby is a 'thing' (kintu), s/he has not become a 'human' (muntu) yet. The most important factor that changes a baby into a human is her/his ability to learn a language. According to this sense, people are human because they speak a language (Fromkin, Rodman \& Hyams, 2011). Similarly, language is a compelling and fantastic system that belongs entirely to the human beings, it is acquired since birth, and it is used in both written and spoken communication (Aksan, 1999). In line with this, it can be said that a language is a heritage that generates humankind, a bridge between human beings and their environment and a means that makes them socialized. Demirel (2014) also states that language is a system that consists of sounds and a means of thinking and 
communicating. All these expressions show how the language is perceived traditionally. On the other hand, the meaning of the language is very different in the globalizing world. Today, language is the key to new competencies, skills and achievements for thousands of universities and billions of university students around the world. Therefore, foreign language teaching is one of the prominent subjects in universities. In the context of the university, there are differences how the foreign language teaching is handled and regulated in different countries.

\subsection{Literature review}

Foreign language teaching at university level is regulated by "Regulation on the Principles to be followed in Foreign Language Teaching and Foreign Language Education in Higher Education Institutions" determines the practices with regard to foreign language teaching in Higher Education in Turkey (Aksu Ataç, Özgan Sucu, Eriçok \& Bulut, 2018). The aim of foreign language teaching is to teach the student the basic rules of the foreign language, to develop the vocabulary of foreign languages, to understand what he reads and hears in a foreign language and to express herself/himself orally or in writing (Regulation on the Principles, 2016). Foreign language courses offered in universities can be divided into two groups as elective and compulsory courses. Elective foreign language courses are optional and taken in addition to compulsory foreign language courses. Elective courses are offered to students with different interests to develop themselves according to their preferences. English, German, French, Russian, Italian, Spanish, Chinese, etc. are among the elective foreign language courses in Turkish higher education system. These courses are generally taught at the basic, intermediate and advanced levels. On the other hand, compulsory foreign language courses are also called service courses or common compulsory foreign language courses. These courses are scheduled for at least two semesters, 2 or 4 hours per week. There may be differences in compulsory foreign language course hours and credits between universities or between different departments in the same university. In addition to these compulsory courses, there are other compulsory foreign language courses with higher weekly hours in certain departments. These courses are given to students starting from the first semester to the last semester in a certain order. The hours and credits of these compulsory courses may increase or decrease according to the objectives of the related departments.

In literature there are some principles that affect foreign language teaching. These principles can be seen as a means of providing more effective consequences in foreign language teaching. Demirel (2014) lists a variety of principles as the basic principles in foreign language teaching. Among them, there is a principle that foreign language teaching should be taught in a certain order. This principle continues from simple to complex, from known to unknown. Similarly, Nation and Macalister (2010) mention several principles regarding teaching a foreign language. Among these principles, there is a principle that emphasizes that foreign language education should include subjects, skills, and abilities in the language in a gradually increasing way. Again, within the teachability principle in the same source, it is stated that the content of the language should be presented with the most appropriate order and when the readiness levels of the students are highest. As can be seen, there are many principles in foreign language education. It can be said that all these principles as well as approaches, methods, techniques have effects on various levels of the language teaching process. However, the principles of presenting the courses in a specific sequence and the graded courses are emphasized. As far as the literature is concerned, the focus of the studies in the literature are generally as follows: factors that are effective in foreign language teaching namely level differences (Gardner, 1997), individual differences (Ehrman, Leaver \& Oxford, 2003), types of personality (Celce-Murcia \& McIntosh, 2001), motivation (Harmer, 2001), individual learning techniques (Dörnyei \& Skehan, 2003; Oxford, 2001). There are also certain studies in the literature that examine foreign language teaching in various contexts: perceptions towards common compulsory courses (Çakıc1, 2007; Genç \& Bilgin Aksu, 2004), compulsory foreign language 
teaching and preparatory classes (Çakır, 2007; Aksu Ataç, Özgan Sucu, Eriçok \& Bulut, 2018; Gökdemir, 2005), problems in foreign language teaching (Oktay, 2015; Can \& Can, 2014; Suna \& Durmuşçelebi, 2013; Arslan \& Akbarov, 2010; Işık, 2008), policy and methods (Çiçek, 2015; Seyratlı Özkan, Karataş \& Gülşen, 2016; Tanrıkulu \& Çiftçi, 2019) and academic achievement (Özer \& Korkmaz, 2016; Kazazoğlu, 2013). On the other hand, it is seen that there are not enough number of studies on graded foreign language courses and their relations in the literature. There are few studies on graded courses given in a certain order from Foreign Language I to Foreign Language VI starting from the first semester to the last semester. Sayın, Koğar \& Çakan (2012) carried out a study on all compulsory courses including Atatürk's Principles and History of Turkish Revolution, Basic Mathematics, Turkish Language, Information Technologies and Foreign Language. Adigüzel \& Özdoğru (2013) carried out a study about developing an academic achievement test for common compulsory Foreign Language I course of universities. As can be seen, there is no direct study on the relationship among graded foreign language courses.

With all this information in mind, the problem of this study is to find out how the academic success scores of the graded foreign language courses have a relationship among them and to what extent these courses are actually prerequisite of each other. This research has a special importance in terms of being the first study examining to what extent the Foreign Language courses (Foreign Language I, II, III, IV, $\mathrm{V}$ and VI) are actually prerequisite of each other. Considering the amount of courses given in a certain order in the scope of graded English course, it will be possible to touch a large audience in foreign language teaching with the results of this study. In this research, it is discussed whether it is correct to assign the higher level Foreign Language course to the students who fail at the beginner level Foreign Language course. It can be said that this study will shed light on the future of foreign language courses and it is thought that the discussions in this study contribute to the body of literature. Considering the amount of courses given in a certain order in the scope of graded English course in university context, it can be possible to touch a large audience with the results of this study.

\subsection{Research questions}

This research tries to find answers the following question:

Is there a significant difference among the academic success scores of the Foreign Language courses (Foreign Language I, II, III, IV, V and VI)?

\section{Method}

\subsection{Research Model}

The model of the study is quantitative correlational survey model. Correlational survey model is one of the quantitative research models. Correlational survey model examinees the exchange correlation between two or more number of variables (Karasar, 2012). As it is aimed to examine whether there is an association change between the academic success scores of the graded Foreign Language courses (Foreign Language I, II, III, IV, V and VI), correlational survey model is thought to be suitable for the aim of the study.

\subsection{Study Group}

The data of the students who took courses from 2012-2013 Academic Year Fall Term to 2014-2015 Academic Year Spring Term in the Tourism Faculty of a public university in Turkey were examined. When the missing data were removed, it was determined that there were 200 students took the graded 
courses from Foreign Language I to the Foreign Language VI respectively. The $\mathrm{z}$ values of these 200 students regarding Foreign Language I, Foreign Language II, Foreign Language III, Foreign Language IV, Foreign Language V, and Foreign Language VI scores are examined. As a result, three students from the Department of Gastronomy and three students from the Department of Tourism and Hotel Management were found to have univariate extreme values in the academic success scores of the related courses and these six students were excluded from the study group. After removing the missing data and endpoints, it is seen that the study group consists of 194 students who took Foreign Language I, II, III, IV, $\mathrm{V}$ and VI courses respectively. The distribution of these students by academic departments is given in Table 1.

Table 1. Distribution of the students according to the academic departments

\begin{tabular}{lcc}
\hline Department & $\mathrm{f}$ & $\%$ \\
\hline Tourism Management (Day Class) & 32 & 16.50 \\
Tourism Management (Evening Class) & 27 & 13.90 \\
Tourism Guidance (Day Class) & 38 & 19.60 \\
Tourism and Hotel Management (Day Class) & 37 & 19.10 \\
Tourism and Hotel Management (Evening Class) & 33 & 17.00 \\
Gastronomy (Day Class) & 27 & 13.90 \\
Total & 194 & 100.00 \\
\hline
\end{tabular}

According to Table 1, the study group consists four day classes and two night classes. There are 194 undergraduate students in the study group. The class with the least number of students is the Gastronomy class with 27 participants $(\mathrm{f}=27 ; 13.90 \%)$. The class with the highest number of students is Tourism Guidance with 38 participants $(\mathrm{f}=38 ; 19.60 \%)$.

\subsection{Data and Data Collection}

The data about the academic success scores of the Foreign Language I, II, III, IV, V, and VI, which the students took gradually from 2012-2013 Academic Year Fall Term to 2014-2015 Academic Year Spring Term, were obtained from Registrar's Office of a public university in Turkey. The data of the research is limited to the academic units of the students and the academic success scores of the Foreign Language courses. Since this research was conducted on the students who took the Foreign Language courses between 2012-2013 Academic Year Fall Term and 2014-2015 Academic Year Spring Term, it was limited to these years. The data were obtained from a public university Registrar's Office in Turkey. Therefore, the data obtained are assumed to be valid and reliable.

\subsection{Data analysis}

Descriptive statistics and frequency analyses were used to describe the academic success scores of the Foreign Language I, II, III, IV, V and VI courses. In addition, Friedman test was used to find out how the academic success scores of the Foreign Language courses have a relationship among them and to what extent these courses are actually prerequisite of each other. One-way analysis of variance 
(ANOVA) is used to determine whether there is a significant difference between two repeated measurements of the same group. The Friedman test is used as an alternative to the one-way analysis of variance for repeated measures if the normal distribution assumption of the data is not provided in each measurement (Gravetter \& Wallnau, 2012). In the Friedman test, each repetitive measurement is sequenced in itself, and dependent medians are compared instead of dependent averages (Alpar, 2013).

If a significant difference is found in the Friedman test, the Wilcoxon Sign-Rank Test is used to determine between which binary groups this difference is (Field, 2009). The effect size for the Wilcoxon Sign-Rank Test is calculated as $r=Z / \sqrt{n}$ (Pallant, 2010). The effect size indicates how much the independent variable is effective on the dependent variable, or in other words, how much of the total variance on the dependent variable is explained by it (Green \& Salkind, 2007). The effect size is interpreted as low for .10, medium for.30 and large effect size for.50 (Cohen, 2007).

\section{Results}

The descriptive statistics related to the academic success scores of the foreign language courses of the students are given in Table 2.

Table 2. The descriptive statistics related to the academic success scores of the foreign language (FL) courses of the students

\begin{tabular}{ccccccccccc}
\hline $\begin{array}{c}\text { Foreign } \\
\text { Language }\end{array}$ & Min & Max & Mean & Median & Mod & SD & $K_{y}$ & $S E_{K_{y}}$ & $B_{S}$ & $S E_{B_{S}}$ \\
\hline FL I & 35 & 87 & 61.70 & 60 & 50 & 10.52 & .44 & .175 & -.21 & .347 \\
FL II & 38 & 88 & 61.36 & 60 & 51 & 12.27 & .38 & .175 & -.70 & .347 \\
FL III & 39 & 83 & 58.21 & 57 & 48 & 9.75 & .72 & .175 & -.20 & .347 \\
FL IV & 26 & 89 & 57.86 & 56 & 56 & 10.89 & .19 & .175 & .11 & .347 \\
FL V & 37 & 89 & 56.83 & 54 & 54 & 11.43 & .61 & .175 & -.16 & .347 \\
FL VI & 28 & 96 & 57.75 & 55.50 & 49 & 13.29 & .47 & .175 & .06 & .347 \\
\hline
\end{tabular}

When the Table 2 is examined, as the range is wide, it can be stated that the students constitute a heterogeneous group in terms of academic success scores of foreign language courses. When the arithmetical averages of the courses students attend each semester are examined, it is observed that there is a continuous decrease until the 5th term. However, after the 5th term, there is a slight increase $\left(M_{F L-V I}=57.75 ; S D=10.89\right)$ in the academic success scores. Absolute $\mathrm{z}$ values of skewness for the Foreign Language I, II, III, V and VI courses, and absolute $\mathrm{z}$ value of kurtosis for the Foreign Language II course are bigger than 1.96. Therefore, the relevant data sets do not show normal distribution (Field, 2009). Moreover, when the central tendency measurements are compared, it is seen that the greatest value is the arithmetic mean. In addition, skewness coefficients are found to be positive. Based on this information, it can be concluded that the data sets for each measurement are left-skewed. KolmogorovSmirnov test is used to test the normal distribution assumption of the data. When Kolmogorov-Smirnov test results are examined, the normal distribution assumption is not provided in each measurement 
$(p<.05)$. Therefore, the Friedman test was used as an alternative to the one-way variance analysis method for repeated measurements.

Table 3. Comparison of academic success scores of foreign language courses of the students

\begin{tabular}{cccccccc}
\hline $\begin{array}{c}\text { Foreign } \\
\text { Language }\end{array}$ & $\mathrm{n}$ & Mean & Median & Ss & Mean Rank & $\chi^{2}$ & $\mathrm{p}$ \\
\hline FL I & 194 & 61.70 & 60 & 10.52 & 4.07 & & \\
FL II & 194 & 61.36 & 60 & 12.27 & 4.01 & & \\
FL III & 194 & 58.21 & 57 & 9.75 & 3.34 & & \\
FL IV & 194 & 57.86 & 56 & 10.89 & 3.34 & & \\
FL V & 194 & 56.83 & 54 & 11.43 & 3.00 & & \\
FL VI & 194 & 57.75 & 55.50 & 13.29 & 3.24 & & \\
\hline
\end{tabular}

When the results of the Friedman test are examined, there is a significant difference among the academic success scores of the foreign language courses $\left[\chi^{2}=53.51, p<.05\right]$. When the average number of sequences obtained for repeated measurements is examined, it is seen that there is generally a decrease in the academic success scores of foreign language courses. To determine between which groups there is a difference, Wilcoxon Sign-Rank Test was used to compare pairs. According to the results of the Wilcoxon Sign-Rank Test, there is no significant difference between the academic success scores for Foreign Language I and Foreign Language II [ $Z=-.45, p>.05, r=.03]$. However, there is a significant difference between Foreign Language I and Foreign Language III [ $Z=-.4 .73, p<.05, r=.34$ ], Foreign Language IV [ $Z=-.4 .62, p<.05, r=.33]$, Foreign Language $\mathrm{V}[Z=-5.06, p<.05, r=.36$ ] Foreign Language $\mathrm{VI}[Z=-.3 .70, p<.05, r=.27]$ respectively. When the median values are examined, there is no significant difference between the Foreign Language I and Foreign Language II course academic success scores. Foreign Language I and Foreign Language II academic success scores are significantly higher than Foreign Language III, IV, V and VI academic success scores. Although Foreign Language I academic success has a low impact on the academic success of Foreign Language II, it has a moderate impact on the academic success of the Foreign Language III, IV, V and VI courses. It can be said that Foreign Language II course has the most effect on Foreign Language V, III, IV and VI courses respectively.

There is a significant difference between the academic success scores of Foreign Language II and academic success scores of Foreign Language III [ $Z=-.4 .53, p<.05, r=.34$ ], Foreign Language IV [ $Z=-$ $.3 .89, p<.05, r=.28]$, Foreign Language $\mathrm{V}[Z=-5.12, p<.05, r=.37]$ and Foreign Language VI $[Z=-.3 .47$, $p<.05, r=.25]$ courses respectively. Students' academic success scores in Foreign Language II course are significantly higher than their scores in the following semesters. Foreign Language II academic success has a moderate impact on the academic success of Foreign Language courses in the following terms. It can be said that Foreign Language II course has the most effect on Foreign Language V, III, IV and VI courses respectively. When the median values were examined, Foreign Language academic success scores of the students decreased by the fifth term, but they increased in the last term.

There is not a significant difference between the academic success scores of Foreign Language III and Foreign Language IV [ $Z=-.914, p>.05, r=.07]$, Foreign Language V [ $Z=-1.904, p>.05, r=.14]$, 
Foreign Language VI [ $Z=-.706, p>.05, r=.05]$ respectively. Similarly, there seems to be no significant difference between the academic success scores of Foreign Language IV and Foreign Language $\mathrm{V}$ [ $Z=-$ 1.347, $p>.05, r=.10]$, Foreign Language VI [ $Z=-.264, p>.05, r=.02]$ and the same situation is valid between the academic success scores for Foreign Language V and Foreign Language VI $[Z=-.914$, $p>.05, r=.14]$. The academic success of Foreign Language II, III, IV, and V have a low impact on the academic success of Foreign Language course in following term. To summarize, there is no significant difference between the academic success scores of Foreign Language I and Foreign Language II. However, the Foreign Language I academic success scores of the students are significantly higher than the Foreign Language II, III, IV, V and VI course academic success scores. Similarly, Foreign Language II academic success scores of the students are significantly higher than Foreign Language III, IV, V and VI academic success scores. However, no significant difference is observed between the academic success scores of the Foreign Language III, IV, V and VI courses.

When the results of the effect size indicate are examined, how much of the total variance on the dependent variable is explained by it respectively. Foreign Language I $(r=.27)$ and Foreign Language II $(r=.25)$ courses have a moderate effect on the academic success of the Foreign Language VI course which is the last level of graded foreign language courses. However, the academic success of Foreign Language I and II courses, have a low effect on the academic success of the Foreign Language V $(r=.14)$, Foreign Language III $(r=.05)$ and Foreign Language IV ( $r=.02)$. In other words, Foreign Language I contributes $27 \%$ of the total variance of the academic success scores of the Foreign Language VI course, while Foreign Language II contributes $25 \%$.

\section{Discussion}

As a result of this research, the academic success scores of Foreign Language I and II are higher than the academic success scores of Foreign Language III, IV, V and VI. As known, Foreign Language I and II courses are among the courses given in the first year of university and these courses constitute the first stage of the foreign language education program. The possible proximity between the courses offered to students at the previous levels (high school or college) and the Foreign Language I and II courses in the first year of university can be seen as the reason for the high academic success scores of the students. This finding coincides with the theoretical knowledge in literature. Nation \& Macalister (2010) state that foreign language education should include subjects, skills, and abilities in the language in a gradually increasing way. Similarly, according to Richards \& Lockhart (1994), in second and foreign language teaching, there are a number of principles determining the internal structure of lessons. These principles are based on different views. One of these principles is simple activities should come before complex ones. In this context, according to the results of this study, the high Foreign Language I and II academic success scores may be due to the fact that the first subjects in these courses are relatively simple or basic. Sayın, Koğar \& Çakan (2012) carried out a study examining the relationship between the hierarchical or graded classes taken by the university freshmen. The aim of this study was to determine the extent to which the graded courses are a continuation of each other. The results of the study show that Foreign Language I and II courses are graded courses. Therefore, it can be said that students who fail in Foreign Language I course have a tendency to fail in Foreign Language II. Bloom (1979) emphasizes that if a lack of learning at one level is not eliminated before moving on to the next level, there will be an increasing differentiation in student achievement.

This study examined the effect sizes of the foreign language courses and reached various results. With this study, it is also found out that which course (Foreign Language I, II, III, IV, and V) is more effective on last stage Foreign Language VI. According to this, Foreign Language I and II courses have 
a higher effect on Foreign Language VI course than that of Foreign Language III, IV, and V. Accordingly, the highest contribution to the Foreign Language VI course comes from Foreign Language I and II courses, not from Foreign Language III, IV and V courses. Therefore, it can be said that the highest contribution to a specific Foreign Language course can be provided by previous levels, not just by the previous level. This finding shows the importance of basic issues in foreign language teaching. The success of the initial level courses may have increased the impact of these courses on the final level. In other words, the effect of gaining a solid foundation in the initial courses taken in the first year makes itself felt even in the last period. Bloom (1979) emphasizes that the units/lessons at the beginning of the series are the most crucial units/lessons in terms of the next lessons.

Learning a second language is a long and complex initiative. The learner is influenced by this process, as the learner goes beyond the limits of the native language and proceeds towards a new language, culture, perspectives and thoughts. There are many factors in the language learning process and language learning is not a set of easy steps that can be programmed in a quick do-it-yourself kit. There are too many points to keep in mind. Learning processes, age and acquisition, instructional variables, context and purpose are among these points (Brown, 2006). Having similarities with these points, this research was also carried on the foreign language learning processes of students who have totally different educational backgrounds, learning styles and speeds from each other. All or some of these factors may have an impact on the results of the study. When the literature is examined, it is clear that these factors are effective in teaching foreign languages. Lightbown \& Spada (2004) assert that the prejudices and beliefs of students and their previous learning experiences can have a negative effect on the language teaching process. Presenting foreign language courses with a linear sequencing approach (in a gradual order) and following a path from simple to complex may also cause some problems for some students. According to Nation and Macalister (2010) linear development assumes that once an item has been presented in a lesson, it has been learned and does not need focused revision. The students who were absent in the class at that time and students with different learning styles and speeds may fail in these foreign language classes. As it can be seen, because of the absenteeism and some other reasons concerning individual differences these language courses may sometimes be problematic. In addition, some of the students who learn foreign languages in the same class can learn foreign languages quickly, while others may not be so fast. Therefore, level differences may occur between students learning foreign languages in the same class (Gardner, 1997).

There are many factors that may have affected the results of this study. First of all, this study is carried out on the students who learn foreign languages within different departments in the Faculty of Tourism. As a result of the difference in departments, students may have some different point of view about learning language. This difference may have affected the learning process. In literature, there are studies in which the effect of department types on foreign language teaching is significant and isn't significant (Çakıcı, 2007; Tok, 2010). Secondly, the study group of this study consists of students who have foreign language education from different lecturers. The fact that teachers are different brings about different practices in the classroom. Harmer (2003) states that the way that teachers talk to students-the manner in which they interact with them is one of the crucial skills. In addition to this, their styles of giving instructions and the amount of time that they talk in the classroom are other factors that make a teacher good or bad. Considering these teacher characteristics, it can be argued that the results of this study are influenced by the different teaching characteristics of different teachers. Thirdly, it can be thought that this research has been carried out on students with very different characteristics. These differences may have an effect on the results of this study because the literature indicates that the differences in learning styles, strategies, personality types, motivation, biological factors and individual differences have great influence on language learning processes (Gass \& Selinker, 2008; Graaff \& Housen, 2009; Güvendir \& Y1ld1z, 2014; Nation \& Macalister, 2010; Oxford, 2001). Finally, another 
factor that may have an impact on the results of this study is the age factor. This study was conducted on university students. A high number of these students work in various hotels, agencies, and companies. For this reason, the sample group of this study can be interpreted as adult foreign language learners. Hilles and Sutton (2001) state that adult students are not generally interested in the environments in which the foreign language is taught academically. Therefore, the beliefs and prejudices of adult students affect the language teaching process negatively (Lightbown \& Spada, 2004). For this reason, it is more effective to teach adult language learners as if you teach a foreign language to children. In the first stages of teaching children foreign languages, the focus is only on speaking, reading and writing activities are not paid much attention. Teaching grammar, on the other hand, includes the structures that are needed for everyday use (filling a job application form, language structures used while on a bus journey, etc.). With this in mind, the results of the foreign language course which are offered to the students in levels may have been affected by the aforementioned features (Hilles and Sutton, 2001; Lightbown \& Spada, 2004) of the adult learners.

The foreign language courses examined in this study are gradually presented to the students in a certain order. Despite this, these courses are not prerequisite of each other legally. Students who fail in Foreign Language III course does not have any limitation to take Foreign Language IV course. This situation can be said to be against the nature of the gradual foreign language courses studied in this research. For this reason, according to the results of this study, it is recommended that graded foreign language courses should be legally prerequisite of each other. In other words, students who fail in Foreign Language III course shouldn't take Foreign Language V course. Otherwise, the level differences may arise in foreign language classes because students who have failed from the previous level will have to learn a foreign language in the same class with the students who are successful in that course. The student is expected to experience learning difficulties when he/she takes an advanced level course without acquiring the desired target behaviors of the course at a previous stage. Moreover, if there are large differences in previous learnings among students, there may be a big difference in terms of students' learning levels or the time they need to reach a certain level of learning (Bloom, 1979). Therefore, the fact that there are level differences among the students in terms of previous learnings may damage the effectiveness of the teaching-learning process in foreign language teaching. Similarly, according to Bloom's Mastery Learning Model, students' previous learnings (cognitive entry behaviors) have 50\% impact on their success. In addition, it is emphasized that in order to ensure the effectiveness of the learning-teaching process, previous learnings about the lessons given in the form of graded series should be learned fully (Bloom, 1979). In line with the Bloom's Mastery Learning Model, it is stated that every new learning is based on previous learning, and each new learning is preparatory for the next ones. In other words, if the subject at each stage is learned fully in graded courses, the level of learning increases when students move on to the next stage (Senemoğlu, 1988). In the study carried out by Kurnaz (2002), it was found out that students with high cognitive entry behaviors were more successful in learning similar educational programs in the following periods.

It should be stated that this study is limited to the grades of foreign language courses of the students. These grades consist of the transcript values of the students over four years. As for the recommendations for future research, more research efforts are needed to determine if the results differ in different universities and different departments. As another research recommendation a mixed model research can be designed by taking the opinions of instructors on prerequisite English courses.

\section{Conclusions}

In conclusion, it was found out that Foreign Language I and II courses and Foreign Language III, IV, V, VI courses are graded among themselves. Complementary to this, Foreign Language I, II, III, IV, V and VI courses are not graded among themselves. Additionally, it was found out that students' academic 
success scores of Foreign Language I and II courses are found to be significantly higher than those of other courses.

\section{Ethics Committee Approval}

The author(s) confirm(s) that the study does not need ethics committee approval according to the research integrity rules in their country (Date of Confirmation: June 12, 2020).

\section{References}

Adıgüzel, O. C., \& Özdoğru, F. (2013). Develop an academic achievement test for common compulsory foreign language I course in universities. Trakya University Journal of Education, 3(2), 1-11.

Aksan, D. (1999). Semantics and semantics of Turkish. Ankara: Engin Publishing.

Aksu Ataç, B., Özgan Sucu, H., Eriçok, B., \& Bulut, M. (2018). The identification of difference between achievement levels of optional and compulsory English preparatory class students. Journal of Language and Linguistic Studies, 14(3), 269-280.

Alpar, R. (2013). Applied multivariate statistical methods. Ankara: Detay Publishing.

Bloom, B. S. (1979). Insan nitelikleri ve okulda öğrenme. (D. A.Özçelik, Trans.). Ankara: Milli Eğitim Basımevi.

Brown, H. D. (2006). Principles of language learning and teaching. White Plains: Pearson Education.

Arslan, M., \& Akbarov, A. (2010). The matter of motivation-method and solution offers in foreign language teaching in Turkey. Seljuk University Journal of Faculty of Letters, 24, 179-191.

Can, E., \& Can, C. I. (2014). Problems encountered in second foreign language teaching in Turkey. Trakya University Journal of Education. 4(2), 43-63.

Çakıcı, D. (2007). The attitudes of university students towards English within the scope of common compulsory courses. Gazi University Journal of Gazi Educational Faculty, 27(3), 21-35.

Çakır, İ. (2007). An overall analysis of teaching compulsory foreign language at Turkish state universities. Journal of Language and Linguistic Studies, 3(2), 250-265.

Çiçek, Y. (2015). Methodology problem in foreign language teaching. International Journal of Languages' Education and Teaching, 2774-2787.

Celce-Murcia, M., \& McIntosh, L. (2001). Teaching English as a second or foreign language. Rowley, MA: Newbury House.

Cohen, J. (2007). Statistical power analysis for the behavioral sciences. New York: Academic Press.

Demirel, Ö. (2014). Foreign language teaching. Ankara: Pegem Academy Publishing.

Dörnyei, Z., \& Skehan, P. (2003). Individual differences in second language learning. In C. J. Doughty \& M.H. Long (Eds). The handbook of second language acquisition (pp. 589-630). Blackwell.

Ehrman, M. E., Leaver, B. L., \& Oxford, R. L. (2003). A brief overview of individual differences in second language learning. System, 31(3), 313-330.

Field, A. (2009). Discovering statistics using SPSS. London: Sage Publications. 
Fromkin, V., Rodman, R., \& Hyams, N. (2011). An introduction to language. Cengage Learning.

Gardner, R. C. (1997). Individual differences and second language learning. In G.R. Tucker \& D. Corson (Eds.) Second language acquisition (pp.33-42). Kluwer Academic Publishers.

Gass, S. M., \& Selinker, L. (2008). Second language acquisition: An introductory course. New York: Routledge.

Genç, G., \& Bilgin Aksu, M. (2004). Attitudes of İnönü University students towards English courses. XIII. National Congress of Educational Sciences, İnönü University, Faculty of Education, Malatya.

Gökdemir, C. V. (2005). Our success in foreign language teaching at our universities. Atatürk University Journal of Graduate School of Social Sciences, 6(2), 251-264.

Graaff, R. D., \& Housen, A. (2009). Investigating the effects and effectiveness of L2 instruction. In M.H. Long \& C.J. Doughty (Eds). The handbook of language teaching (pp. 727-755). WilleyBlackwell.

Gravetter F., \& Wallnau, B. W. (2012) Statistical for behavioral sciences. Canada: Thomson Learning.

Green, S. B., \& Salkind, N. J. (2007). Using SPSS for Windows and Macintosh analysing and understanding data. New Jersey: Pearson.

Güvendir, E., \& Yıldı, I. G. (2014). Language acquisition. Ankara: Anı Publishing.

Harmer, J. (2001). The practice of English language teaching. Essex: Pearson.

Harmer, J. (2003). How to teach English. Essex: Longman.

Hilles, S., \& Sutton, A. (2001). Teaching adults. In Celce-Murcia \& L. McIntosh (Eds). Teaching English as a second or foreign language (pp.385-399). Heinle\&Heinle Thomson Learning.

Iş1k, A. (2008). Where do the mistakes in our foreign language education come from? Journal of Language and Linguistic Studies, 4(2), 15-26.

Karasar, N. (2012). Scientific research methods. Ankara: Nobel.

Kazazoğlu, S. (2013). The effect of attitude towards Turkish and English classes on academic achievement. Education and Science, 38(170), 294-307.

Kurnaz, A. (2002). İlköğretim 4. sınıf sosyal bilgiler dersinde öğrencilerin duyuşsal ve bilişsel giriş davranışlarının farklı değişkenler açısından incelenmesi (Unpublished MA thesis). Selçuk University, Konya.

Lightbown, P. M., \& Spada, N. (2004). How languages are learned. Oxford: Oxford University Press.

Nation, I. S. P., \& Macalister, J. (2010). Language curriculum design. Routledge.

Oktay, A. (2015). Foreign language teaching: A problem in Turkish education. Procedia-Social and Behavioral Sciences, 174, 584-593.

Oxford, R. L. (2001). Language learning strategies. In M. Celce-Murcia \& L. McIntosh (Eds). Teaching English as a second or foreign language, (pp.359-366). Heinle \& Heinle Thomson Learning.

Özer, B., \& Korkmaz, C. (2016). Factors Affecting Student Achievement in Foreign Language Teaching. EKEV Journal of Academy, 20(67), 59-84.

Pallant, J. (2010). SPSS survival manual: A step by step guide to data analysis using SPSS. Maidenhead: Open University Press/McGraw-Hill. 
Regulation on the Principles to be followed in Foreign Language Teaching and Foreign Language Education in Higher Education Institutions. (2016, 23 March). Resmi Gazete (Issue: 29662).

Richards, J., \& Lockhart, C. (1994). Reflective teaching in second language classroom. Cambridge University Press.

Sayın, A., Koğar, H., \& Çakan, M. (2012). Canonical Correlation Technique: The Case of Classroom Teaching Department. Journal of Measurement and Evaluation in Education and Psychology, 3(1), 210-220.

Senemoğlu, N. (1988). Öğretimin geliştirilmesi. Eğitim ve Bilim, 12(67), 27-31.

Seyratlı Özkan, E., Karataş, İ. H., \& Gülşen, C. (2016). The analysis of foreign language education policies in Turkey during 2003- 2013. Journal of Research in Education and Teaching, 5(1), 245254.

Suna, Y., \& Durmuşçelebi, M. (2013). A compilation work about why Turkey suffers from learning and teaching English. OPUS International Journal of Society Researches, 3(5), 31-48.

Tanrıkulu, L., \& Çiftçi, H. (2019). The analysis of productive skills in foreign language teaching methods. International Journal of Language Academy, 7(4), 232-245.

Tok, H. (2010). Investigation of affective attitudes of university students about English course according to some variables. Journal of National Education, 40(185), 90-106.

\section{Aşamalı yabancı dil dersleri akademik başarı puanları arasındaki ilişki}

\section{$\ddot{O} \mathbf{z}$}

Bu çalışmanın amacı öğrencilerin aşamalı olarak aldığı yabancı dil dersleri (Yabancı Dil I, II, III, IV, V, VI) akademik başarı puanları arasında nasıl bir ilişkinin bulunduğunun ve bu derslerin gerçekte ne derece birbirinin devamı olduğunun incelenmesidir. Bu çalışma nicel bir çalışma olup ilişkisel tarama modelindedir. Araştırmanın çalı̧̧ma grubunu yabancı dil derslerini Türkiye'de bir devlet üniversitesinin Turizm Fakültesi'nde 2012-2013 akademik yılı güz döneminden 2014-2015 akademik yılı bahar dönemine kadar aşamalı bir şekilde alan 194 öğrenci oluşturmaktadır. Araştırma sonucunda öğrencilerin Yabancı Dil I ve II dersleri akademik başarı puanlarının ve Yabancı Dil III, IV, V ve VI dersleri akademik başarı puanlarının kendi aralarında aşamalılık gösterdiği ortaya çıkmıştır. Dolayısıyla araştırmanın sınırlılıkları doğrultusunda genel bir değerlendirme yapıldığında, Yabancı Dil I, II, III, IV, V, VI dersi akademik başarı puanlarının bütüncül bir şekilde aşamalılık göstermediği belirtilebilir. Bunun yanı sıra bu çalışma ile Yabancı Dil I ve II akademik başarı puanlarının gelecek dönemlerdeki aşamalı yabancı dil dersi akademik başarı puanlarından manidar bir şekilde daha yüksek olduğu sonucuna ulaşılmıştır. Bu doğrultuda isim, içerik ve kullanılan kitaplar bakımından aşamalılık gösteren bu derslerin, gerçek anlamda Bloom'un Tam Öğrenme Modeli'ne uygun şekilde aşamalı hale getirilmesi tavsiye edilmektedir. Bu bağlamda aşamalı yabancı dil derslerinin öğrenciler tarafından seçilmesinde de bu aşamalılı̆̆ın göz önünde bulundurulması sağlanmalıdır. Aşamalı yabancı dil derslerinin herhangi bir düzeyinden başarısız olan öğrencilerin bir üst aşama olan dersi almalarının engelleyecek şekilde yönetmelik değişikliklerinin yapılması önerilmektedir.

Anahtar Sözcükler: aşamalı İngilizce dersleri; akademik başarı; ön koşullu dersler; tam öğrenme modeli, yabancı dil olarak İngilizce 


\section{AUTHOR BIODATA}

Recep Gür is an assistant professor in the Department of Measurement and Evaluation, Faculty of Education at Anadolu University, Eskişehir, Turkey. He completed his undergraduate studies at the Department of Secondary Mathematics Teaching at Ahmet Keleşoğlu Faculty of Education at Selçuk University. Then, he took his Master's (2013) and PhD (2017) degrees at the Department of Measurement and Evaluation at Ankara University. He worked as a research assistant and an assistant professor in the Department of Measurement and Evaluation at Erzincan Binali Yıldırım University. Currently, he has been working as an assistant professor at Anadolu University. He has many papers presented in international and national conferences, articles taking place in peerreviewed journals scanned by national and international indexes, international book chapters and a software development work named "data analysis guide" (www.verianalizirehberi.com). Multivariate statistics, achievement test and scale development, computerized adaptive tests, academic achievement of scholars, measurement precision and test security are among his study topics.

Barış ERIÇOK is a lecturer and he teaches English at the School of Foreign Languages at Hacı Bektaş Veli University, Nevşehir, Turkey. He has previously taught at a governmental secondary school and Ordu University. He received his bachelor's degree from Anadolu University in English Language Teaching and master's degree from Gaziosmanpaşa University. For his master's degree, he studied emotional intelligence (EQ) and leadership competencies of school leaders. For his PhD degree, he studied Educational Administration, Supervision, Planning and Economics at Hacettepe University. The author worked on the internationalization of higher education in Turkey for his PhD dissertation. In the future, he plans to study interdisciplinary subjects in the context of education. He sincerely welcomes anybody who wants to contact with him on his email: barisericok [at] gmail.com. He is open to collaboration and networking at every level. 